\title{
Between national and European foreign policy: the role of Latvia and Romania in the EU's policy towards Central Asia
}

\section{Fabienne Bossuyt}

To cite this article: Fabienne Bossuyt (2017): Between national and European foreign policy: the role of Latvia and Romania in the EU's policy towards Central Asia, Southeast European and Black Sea Studies, DOI: 10.1080/14683857.2017.1361897

To link to this article: http://dx.doi.org/10.1080/14683857.2017.1361897

Published online: 10 Aug 2017.

Submit your article to this journal $\sqsubset$

Q View related articles ๘

View Crossmark data $\complement$ 


\title{
Between national and European foreign policy: the role of Latvia and Romania in the EU's policy towards Central Asia
}

\author{
Fabienne Bossuyt \\ Department of Political Science, Ghent University, Gent, Belgium
}

\begin{abstract}
This article explores whether and to what extent new member states of the European Union (EU) seek to pursue their national foreign policy goals towards Central Asia through the EU rather than bilaterally. To do so, it focuses on Latvia and Romania. While the article finds evidence of Romanian attempts to project its interests in the region onto the EU level, Latvia appears to rely more extensively on the EU level to pursue its goals towards Central Asia. Using insights from the literature on Europeanization of national foreign policy, the article explains this finding with reference to four variables that determine whether a member state will seek to upload its national foreign policy preferences onto the EU level, namely the perceived salience of the policy goals, the extent to which member states can carve out a niche, their perceived capabilities and the level of Europeanization of their national foreign policies.
\end{abstract}

\section{ARTICLE HISTORY}

Received 21 January 2016

Accepted 24 July 2017

\section{KEYWORDS}

European Union; Central Asia; Latvia; Romania; foreign policy

\section{Introduction}

Research on the involvement of the new member states of the European Union (EU) in the EU's external policies remains very scarce, in particular when it concerns regions beyond the Eastern neighbourhood. In contributing to this literature, this article focuses on the involvement of two new member states, namely Latvia and Romania, in the EU's policy towards Central Asia. ${ }^{1}$ In particular, it explores their foreign policy goals towards the region and examines to what extent they try to pursue these through the EU rather than bilaterally.

Theoretically, the article draws on insights from the literature on Europeanization (of national foreign policies) and European foreign policy analysis. In doing so, it starts from three assumptions. To begin with, in the area of foreign policy, Europeanization is generally understood as 'a process of change manifested as policy convergence (both top-down and sideways) as well as national policies amplified through EU policy (bottom-up projection)' (Wong and Hill 2011, 4). While the article is concerned with the latter dimension of Europeanization, it assumes that the processes of bottom-up projection ('uploading') and policy convergence ('downloading') exist in a circular relationship (Baun and Marek 2013, 10; Hill and Wong 2011, 219). Second, the article assumes that member states will 
attempt to project certain national preferences regarding foreign policy onto the EU level because - if successful - it can allow them to pursue and even expand those foreign policy objectives beyond those attainable with domestic capabilities (Baun and Marek 2013, 16; Hill and Wong 2011, 222; Keukeleire and Delreux 2014, 132; Pastore 2013). Third, while the national foreign policies of EU member states have each experienced a certain degree of Europeanization, the member states' foreign policies continue to be shaped by traditional foreign policy forces of pragmatism, cost-benefit analysis and instrumentalism, both in their motivations and their strategic behaviour (Hadfield, Manners, and Whitman 2017). As Hadfield, Manners, and Whitman (2017) claim, EU member states directly experience 'the tension between the practice of Europeanization and the pull of sovereignty'. Moreover, given that the EU's legal competence in the area of foreign policy is still low, member states continue to conduct foreign policy issues in parallel to, separately from, or even in opposition to the EU.

Starting from these assumptions, the article is interested in exploring whether and to what extent new EU member states seek to pursue their national foreign policy goals towards Central Asia through the EU rather than bilaterally. Based on insights from the literature on Europeanization of national foreign policy (Baun and Marek 2013; Keukeleire and Delreux 2014, 116-134; Wong and Hill 2011), it identifies four conditions under which member states are likely to attempt to project national foreign policy preferences onto the EU level. These include the perceived salience of a policy goal, the extent to which member states can carve out a niche, member states' perceived capabilities and the level of Europeanization of the national foreign policies. Compared to the top-down dimension of Europeanization, the bottom-up dimension has so far received only little attention (Angelescu 2011a; Baun and Marek 2013; Denca 2009). Moreover, the focus of existing studies is mostly empirical and is geared towards the question of effectiveness of member states' uploading attempts rather than towards the uploading at such. In this context, therefore, the framework presented in this article should not be considered as a fully conclusive and exhaustive theoretical account of the conditions determining when member states will seek to project national preferences, but rather as a heuristic tool developed to help us explore whether and to what extent EU member states seek to pursue their national foreign policy goals towards Central Asia through the EU.

Until now, research on the involvement of the new member states in the EU's external policies has focused predominantly on the Eastern neighbourhood (see e.g., Angelescu 2011b; Copsey and Pomorska 2010; Galbreath 2006; Galbreath and Lamoreaux 2007; Kesa 2011; Pisarska 2008; Raik and Gromadzki 2006). As such, there is very little knowledge about their involvement and interests in EU policies towards regions further afield, including Central Asia. ${ }^{2}$ Central Asia stands out as an interesting case, in particular for the new member states that were part of the Soviet bloc or Soviet Union. The shared history and common economic links create the intuitive expectation that the former communist/ Soviet EU member states will have more pronounced foreign policy goals towards Central Asia than the EU member states, which were not part of the Soviet bloc or Soviet Union. Moreover, Central Asia poses significant security challenges to Europe - and arguably more so to Central and Eastern Europe and the Baltic region than to other parts of Europe given its closer geographic location and/or logistical links (see e.g., Tiirmaa-Klaar 2006) - , including Islamic terrorism, drugs trafficking, organized crime and the risk of regional instability due to possible spillover from Afghanistan. Given that these member states' primary foreign policy concerns, including their interest in a closer EU relationship with 
the Eastern neighbourhood, are related to security issues (Bilčík 2010; Ozolina and Rostoks 2006), Central Asia is an interesting case for exploring to what extent security concerns also inform their interests in the EU's foreign and development policies towards regions beyond the Eastern neighbourhood.

The article focuses on two new member states: Latvia and Romania. Compared to other new EU member states, Latvia and Romania have relatively strong ties with Central Asia (Gower 2010; Jēkabsone 2013; Marin 2013). Therefore, we can expect that - compared to other new member states, which have less developed relations with and less outspoken interests in the region - Latvia and Romania are more likely to actively use the EU level in pursuit of their policy goals towards Central Asia. This means that if we do not find evidence of Latvian and Romanian attempts to project their national interests in Central Asia onto the EU level, we can assume that other new member states will also not attempt to influence the EU's policy towards Central Asia. ${ }^{3}$ However, as will be shown below, Latvia has even more pronounced interests in the region than Romania, which suggests that it is likely to be more active than Romania at the EU level.

At the same time, bearing in mind Hadfield, Manners, and Whitman (2017) conceptualization of EU member states' national foreign policy as manifesting a tension between Europeanization and sovereign imperatives, we expect Latvia and Romania to also undertake foreign policy action towards Central Asia in parallel to or autonomously from (their involvement in) EU policy, in particular in policy areas where they perceive to have the capacities and resources to 'go it alone'.

Methodologically, the article relies on data gathered through document analysis of official documents from the EU and from the Romanian and Latvian governments, complemented with insights from, on the one hand, semi-structured interviews with EU and national officials, and secondary sources, including academic literature and publications from think tanks, on the other.

The remainder of the article is structured as follows. Following this introduction, the analytical framework is presented along with the theoretical assumptions that underpin the analysis in the empirical sections. To do so, this section draws on the literature on Europeanization of national foreign policy and European foreign policy analysis. In the next section, we outline the interests and policy goals of Latvia and Romania towards Central Asia, and review their diplomatic, political, economic and cultural relations with the five Central Asian states. Next, the article analyzes the extent to which Latvia and Romania seek to project their interests in the region onto the EU level. In doing so, it also explores which goals they pursue in parallel to or independently of (their involvement in) EU policy. This section ends by offering some tentative explanations by making reference to the four conditions under which member states are likely to engage in uploading. The final section summarizes the main findings and provides some broader reflections, first, on what these findings tell us about the new member states as foreign policy entrepreneurs and, second, on how the findings can be used for further research.

\section{Between Europeanization and nationalization}

\subsection{Uploading in order to amplify}

The article starts from the assumption that EU member states will seek to project or 'upload' certain national foreign policies objectives onto the EU level because of the possible 
'amplifying' effect. Bottom-up Europeanization in the area of foreign policy may enable 'member states to pursue and even expand foreign policy objectives (in specific regions or with regard to specific themes) beyond those attainable with domestic capabilities' (Keukeleire and Delreux 2014, 132). If a state successfully manages to upload a national foreign policy goal onto the EU level, it can rely on budgetary, diplomatic and economic support from the EU institutions and other member states, which allows this national foreign policy goal to be pursued more intensively and with a higher potential impact (Keukeleire and Delreux 2014, 132; also see Hill and Wong 2011, 222). In this regard, the article thus takes a rational institutionalist approach in the sense that it assumes EU member states to act strategically to attain their preferences.

While it is generally acknowledged that EU foreign policy is highly subject to the interests of the large member states (in particular, Germany, France and the UK), smaller member states can also leave their mark on the EU's foreign policy and succeed in projecting their interests onto the EU level (Denca 2009, 2013; Nasra 2011; Pastore 2013; Wong and Hill $2011,7)$. EU membership allows them to pursue a more ambitious national foreign policy, backed by the EU's political and economic weight and international standing (Denca 2009; Popescu 2010). Smaller member states also benefit strongly from the increased access to information and resources, which hugely exceed their own capabilities (Denca 2009, 402). As such, new member states, and in particular the smaller countries, tend to perceive EU membership and integration in the field of foreign policy as carrying more benefits than losses.

The foreign policy priorities of the new EU member states mostly concern relations with their immediate neighbours and/or countries situated in their relative vicinity (Baun and Marek 2013). As such, the main geographic priorities of most new member states are the Eastern neighbouring countries of the EU and/or the countries of the Western Balkans (see e.g., Bilčík 2010, 135). These priorities are clearly reflected in their involvement in the EU foreign policy-making process, as these member states tend to be most active in the EU policy issues relating to those two regions. The observation that the new member states have been attempting to project their interests onto the EU level, suggests that they have moved beyond their respective accession legacies (Baun and Marek 2013). After a decade of institutional adaptation to the workings of the EU foreign policy-making process, most new member states now master the Brussels game and do not shy away from playing along with the older member states (Baun and Marek 2013; Bilčík 2010; Pastore 2013; Vilpisauskas 2011). Both in light of the economic crisis and the pressures of globalization and as a result of 'top-down' Europeanization, many of the new member states are in the process of further redefining their national foreign policy, manifesting an increased interest in bolstering ties with countries and regions beyond their immediate vicinity. As mentioned above, however, the extent to which they are attempting to do so through the EU rather than bilaterally has so far received little scholarly attention.

\subsection{Continued centrality of national sovereignty}

At the same time, most of the new member states - like many other member states - are opposed to deeper EU integration in the area of foreign policy and prefer this domain to remain intergovernmental. This points to the continued centrality of national sovereignty as the guiding principle for foreign policy. As Hadfield, Manners, and Whitman (2017) assert, 
EU member states directly experience 'the tension between the practice of Europeanization and the pull of sovereignty'. Foreign policy-making in the European capitals is still informed by demands of national decision-makers to follow sovereign imperatives in as many areas as possible, both procedurally and in terms of substance. In this perspective, national foreign policy is thus the result of a reconciliation of sovereign imperatives, which 'explain the enduring pragmatism and even obstructivism that characterizes many member states' foreign policy' (Hadfield, Manners, and Whitman 2017).

Moreover, as the EU's legal competence in the area of foreign policy is still low, member states continue to conduct foreign policy issues in parallel to, separately from, or even in opposition to the EU. Based on this conceptualization, member states' foreign policy should thus be observed across the interface of forces of Europeanization and national imperatives (Hadfield, Manners, and Whitman 2017). The extent to which national sovereign imperatives operate in foreign policy is different in all 28 member states and varies on a policy by policy basis (Hadfield, Manners, and Whitman 2017).

National preferences and interests of EU member states are shaped by a broad range of factors, including (perceived) size, geography, economy, historical experience, domestic politics, institutional settings - such as coordination of EU policy-making - , external alliances, international developments and perceived national vulnerabilities and weaknesses (Bilčík 2010; Copsey and Haughton 2009; Wong and Hill 2011). As Wong and Hill $(2011,3)$ point out, national preferences and interests also 'reflect a country's sense of national identity, including its basic values and perceptions of what it stands for in the world'. In the case of the EU member states that were part of the Soviet bloc or Soviet Union, national preferences and interests in the area of foreign policy are strongly influenced by the experience of and the security and economic dependencies from the communist and Soviet era, as well as by the political geography of the countries' historical statehood (Bilčík 2010, 142; Copsey and Haughton 2009; Vilpišauskas 2011).

In examining to what extent Latvia and Romania pursue their foreign policy goals towards Central Asia through the EU rather than bilaterally, these factors thus need to be taken into account. Therefore, we might find some variation in the degree to which Latvia and Romania each use the EU level to pursue their interests in Central Asia not only because Latvia's interests are more pronounced than those of Romania, but also given the variation that they display on a number of these preference-shaping factors, including history and geography. To begin with, although they both are former socialist states and they share a recent transition from socialist and authoritarian states to democratic and modern liberal states, Latvia and Romania have different historical trajectories and experiences with statehood. Latvia was part of the Soviet Union and only regained its independence as a sovereign state in 1991. Romania was a USSR satellite state, but although it fell under the influence sphere of Moscow, it assumed a bit of a 'dissident' position within the Soviet bloc and enjoyed more autonomy compared to the other USSR satellite states. Second, although they are both geostrategically located countries - an asset which they both want to take full advantage of - , they have a different geographical location. Latvia is situated in northern Europe, next to the Baltic Sea, while Romania is located in Central Eastern Europe, next to the Black Sea. Third, they differ in size. Romania is the second largest new EU member state, after Poland, and tends to be regarded as a medium-sized country, while Latvia is one of the smallest EU member states. However, it should be noted that Romania, given its limited resources and Gross Domestic Product per capita, is sometimes approached as 
a small state (see e.g., Malova et al. 2010). ${ }^{4}$ Finally, they have a different accession history. Latvia joined the EU in 2004 while Romania became a member in 2007.

\subsection{Conditions for uploading}

Based on insights from the literature on Europeanization of national foreign policy, the article identifies four conditions under which member states are likely to attempt to project national foreign policy preferences onto the EU level. A first condition pertains to the perceived importance of a policy goal. Member states will normally only try to project national preferences onto the EU when these concern issues that they consider very important (Baun and Marek 2013, 213,218). In other words, if an issue is not considered a policy priority, they will not invest significant effort in trying to influence the EU on that matter. The factors determining the (perceived) importance of a policy issue are of course closely linked to the preference-shaping factors mentioned above.

Second, attempts at uploading tend to occur when member states have carved out a niche for themselves, a policy area or issue on which they can provide specific expertise or experience (Baun and Marek 2013, 16, 212, 213, 218, 219).

Third, the extent to which member states will pursue national foreign policy goals through the EU depends on their perceived capabilities. Attempts at uploading are more likely when member states feel they cannot do it alone and that their interests will be better served when going through the EU (Baun and Marek 2013, 223; Keukeleire and Delreux 2014, 132; Wong and Hill 2011). This condition is of course particularly salient for smaller member states, as they have limited domestic resources and capacities (see e.g., Pastore 2013)

A fourth and final condition regards the level of Europeanization of the member states' national foreign policies. The more their foreign policies - including the governmental structure, bureaucracy and organizational infrastructure of their foreign policy machinery - are adapted to the EU's foreign policy (i.e., downloading dimension of Europeanization), the more likely they are to attempt to project national foreign policies objectives onto the EU level (Baun and Marek 2013, 11, 222, 223). This condition strongly reflects the assumption that the bottom-up and top-down dimensions of Europeanization exist in a circular relationship (see above).

In what follows, the article first outlines Latvia's and Romania's interests and foreign policy goals towards Central Asia, before examining whether and to what extent they pursue these interests and goals through the EU rather than bilaterally. The data examined cover the period 2008-2017, with most attention focused on the last five years (2013-2017).

\section{Latvian and Romanian interests in Central Asia}

Both Latvia and Romania have a strong diplomatic presence in the region and maintain relatively well-established and long-lasting relations with the Central Asian states, in particular with Kazakhstan, Uzbekistan and Turkmenistan, the three largest and most important countries in the region. While their diplomatic relations with the Central Asian states go back to the early days of the latter's independence, their ties with the region have intensified in recent years. The outline of their interests and policy objectives towards Central Asia presented below shows that Latvia's interests in Central Asia are wider and more pronounced than those of Romania. In the period 2012-2015, Central Asia was mentioned 
as a priority region in Latvia's foreign policy strategy, alongside the EU's Eastern neighbourhood (Latvian Ministry of Foreign Affairs 2013, 2016a). As we will see below, this coincided with the preparation and implementation of Latvia's Presidency of the Council of the EU. Although Central Asia has now taken a back seat to the Eastern Partnership in Latvia's foreign policy, the region still attracts considerable attention from Latvia (Latvian Ministry of Foreign Affairs 2017; Pastore 2017). In Romania's foreign policy, up until now, Central Asia has not been considered a priority and has received relatively little attention (Romanian Government 2009, Romanian Ministry of Foreign Affairs 2017b). Nevertheless, Romania has considerable interests in the region (Gower 2010, 42; Interview 1), stemming to a large extent from its ambition to take maximum use of its geostrategic location within the Black Sea region (Romanian Government 2009; Romanian Ministry of Foreign Affairs 2014). Latvia's increased interest in Central Asia is motivated mainly by security and economic reasons. Romania's interests in Central Asia are mostly economic and energy related. Security concerns also play a role, but to a lesser extent than in the case of Latvia.

\subsection{Romania's interests in Central Asia}

Romania is mainly focused in the region on expanding its relationships with Kazakhstan, Turkmenistan and Uzbekistan. Its interest in Kyrgyzstan and Tajikistan is marginal, for the pragmatic reason that these countries have little to offer. Kazakhstan is its closest and main partner in Central Asia. The relationship is of strategic importance to Romania (Interview 1; Marin 2013,2). The principal area of cooperation between the two states is the energy sector and derived industries (Gower 2010, 43; Interview 1. The considerable economic stakes and long-standing diplomatic ties also translate in close political support. For instance, Romania was a strong supporter of Kazakhstan's chairmanship of the Organization of Security and Cooperation in Europe (OSCE) in 2010 (Gower 2010, 43; Marin 2013, 2), as well as of its bid to host the international exhibition 'Expo 2017' (Marin 2013, 2).

Romania is drawn to Central Asia's market potential, which offers opportunities for Romanian exports of industrial products and for Romanian know-how in the field of hydrocarbons, drilling equipment and land improvement (Romanian Ministry of Foreign Affairs 2014, 2017a). Although significantly expanded in recent years, Romanian exports to Kazakhstan - its main trade partner in the region - remain low (84.3 million US dollar in 2014) and consist mainly of electromechanical equipment (31.6\%), steel (16.3\%), chemical products $(13.6 \%)$, transport vehicles $(11.5 \%)$, food products $(8.8 \%)$ and wood (8.8\%) (Embassy of Romania in the Republic of Kazakhstan 2017a). By contrast, Romanian imports from Kazakhstan are quite high, amounting to more than 3 billion US dollar in 2014 (Embassy of Romania in the Republic of Kazakhstan 2017a). As a net oil importer and an important oil processing market, Romania is one of the Kazakhstan's largest export markets and top FDI destinations (Marin 2013, 2). Because the Kazakh state oil company KazMunaiGas owns the Romanian company Rompetrol, Kazakhstan is one of the largest contributors to Romania's national budget, providing revenues of more than $€ 1.5$ billion a year (Marin 2013,2). This shows that Central Asian countries should no longer be seen as passive entities, submitted to the agency of external actors (Cooley 2012).

Energy interests are the main driving factor behind Romania's closer engagement with Central Asia. They also drive its relations with Turkmenistan, its second partner in Central Asia. Together with Kazakhstan, Turkmenistan plays an important role in realizing Romania's 
ambition to become the main energy and transport hub in the Black Sea region. Romania wants to take full advantage of its potential as a key access route to the European market for Caspian Sea energy resources (Romanian Government 2009; Romanian Ministry of Foreign Affairs 2014, 2017b), a position which it can play it out against both its European partners and its Central Asian partners. Hence, Romania is one of the main supporters of the establishment of a Trans-Caspian corridor to transport Caspian Sea gas to Europe, the so-called Southern Corridor, which would help to diversify gas transit routes and thus reduce Europe's dependence on Russian gas (Interview 1; Romanian Ministry of Foreign Affairs 2011, 2017b).

However, the 'relative' vicinity of Central Asia to the Black Sea region also holds a security risk for Romania, in the sense that potential instability in Central Asia could affect Romania's energy security. Other security threats for Romania include illegal migration, terrorism and drugs trafficking, notably from Afghanistan. Moreover, as is the case for almost all new member states, Afghanistan and the NATO mission there were an important foreign policy issue for Romania. Since possible instability in Afghanistan may spill over to the Central Asian states, Romania has an interest in contributing to the country's 'security climate needed for stabilization and reconstruction activities' and therefore also participates in NATO's post-ISAF activities in Afghanistan (Romania's Permanent Delegation to NATO's 2017). Central Asia is only a minor beneficiary of Romanian aid and is not considered a priority region for Romanian development cooperation. Some technical assistance has been offered to the region, namely in the areas of water management and diplomacy training, but most of it has been channelled through the EU and UNDP (RoAid 2016; Romanian Ministry of Foreign Affairs 2012).

\subsection{Latvia's interests in Central Asia}

For Latvia, NATO's mission in Afghanistan and its gradual phasing-out was a major foreign policy issue (Latvian Ministry of Foreign Affairs 2012, 2013; Pastore 2016). Like Romania, Latvia considers NATO membership as the foundation for its national security (Jêkabsone 2013; Ozolina and Rostoks 2006; Tiirmaa-Klaar 2006). Hence, it fully supports NATO's policy and concerns towards Afghanistan and, by extension, Central Asia. However, compared to Romania, there are more interests at stake for Latvia. Apart from participating in the International Security Assistance Force (ISAF) mission, Latvia was a leading actor in NATO's cargo traffic to Afghanistan through the Northern Distribution Network (NDN), which ran from the Baltic ports overland and by air to Afghanistan. Latvia acted as an entry point for both an air supply line and a rail supply line. The latter went across Russia and Central Asia, thereby taking advantage from the railway infrastructure and networks that were established in the Soviet era. Moreover, Latvia's embassies in Uzbekistan and Kazakhstan - whose territories have been used by NATO for transit from and to Afghanistan - functioned as 'NATO Contact Point Embassies' to support NATO transit activities (Interview 4; Latvian Ministry of Foreign Affairs 2013). The NDN held considerable economic benefits for Latvia, especially for the transport and logistics industry operating in and around the sea ports and Riga's international airport (Interview 4; Latvian Ministry of Foreign Affairs 2012, 2013). Before Russia decided to close the NDN in 2015, Latvia even hoped that the transport corridor would also be used for commercial cargos after the end of ISAF (Interview 4). ${ }^{5}$ Since 2015, Latvia has been participating in NATO's support mission for Afghanistan's national security forces (Vanaga 2017). 
Latvia also has other security concerns relating to Central Asia. Latvia is witnessing increasing cases of drugs trafficking, human trafficking, organized crime and illegal migration all coming from Central Asia through Russia. Therefore, Latvia has a direct interest in improving border management and drugs control capacities in the region (Interview 2).

Apart from contributing to security and stability in Central Asia, Latvia hopes to strengthen its economic presence there. Despite its very different political and economic trajectory since the collapse of the Soviet Union, Latvia maintains well-established political relations with the Central Asian states and enjoys a very positive image in the region (Interview 2, Interview 4). Its bilateral relations with the countries are mostly centred on strengthening economic cooperation (Pastore 2017). Like Romania, bilaterally, Latvia's main interest lies with Kazakhstan, Uzbekistan and Turkmenistan, as these countries have most economic potential.

Since a couple of years, Latvia has been offering development assistance to the region, in particular to Tajikistan and Kyrgyzstan, the two poorest countries (Jēkabsone 2013; Latvian Ministry of Foreign Affairs 2012, 2013, 2014a, 2017). While its funding for development cooperation is very limited due to budgetary restraints, Latvia is committed to providing assistance to the region 'in areas where there is demand for Latvian expertise' (Latvian Ministry of Foreign Affairs 2013, 14). In Central Asia, Latvia mostly offers technical assistance for border and customs control, but also for food security and local governance (Latvian Ministry of Foreign Affairs 2014a, 2017). Previously, like in Romania, Latvian development cooperation focused predominantly on the Eastern Partnership countries (in particular, Moldova, Ukraine, Belarus and Georgia) and on Afghanistan. However, with Central Asia having become a new priority for Latvia's foreign policy, the region has now been added as a priority region for Latvian development assistance. Latvia openly concedes that 'development cooperation is an important foreign policy tool, which is especially important to Latvia in its foreign policy priority regions: the Eastern Partnership and Central Asian countries' (Latvian Ministry of Foreign Affairs 2013, 14).

In addition, Latvia has been actively seeking to attract students from Central Asia. The number of Central Asians among the foreign student population in Latvian universities is very high, with currently no less than 800 students from Uzbekistan alone (Interview 4; Pastore 2016). Riga School of Law offers a European law and economics study programme specifically for citizens from the Western Balkans, the Eastern Partnership and Central Asian countries (Latvian Ministry of Foreign Affairs 2016b; Pastore 2016).

Latvia is very interested in further developing its potential as a transport hub for Chinese and Central Asian exports. Already since Soviet times, Latvia's sea ports have been a central transit base for exports from Central Asia to Europe. Today, logistics and transit services continue to be the main area of Latvia's economic cooperation with Central Asia because of their common (railway) transportation infrastructure. Most of Uzbekistan's cotton exports to Europe, for instance, passes through the port of Riga (Interview 2; Interview 4). Kazakhstan has a transit terminal near the port of Ventspils for its export of grain to Europe (Peyrouse 2009, 9) ${ }^{6}$ and Tajikistan uses the port of Riga for the transit of its aluminium exports to Europe (Interview 2). As with Romania, Kazakhstan is Latvia's main trade partner in Central Asia. While trade with Kazakhstan is dominated by the imports of oil, it is less so than in the case of Romania, even though trade between Kazakhstan and Latvia remains very limited; in 2015, exports amounted to $€ 42$ million and imports to $€ 11$ million (Central Statistical Bureau of Latvia 2017). Latvia has been increasingly eager to 
expand trade relations and explore new business opportunities in Kazakhstan as well as in the other countries, including in the fields of technology transfer, agriculture, pharmaceuticals, metalwork, tourism and education (Jēkabsone 2013, 1, 2; Latvian Ministry of Foreign Affairs 2013; Pastore 2017, 152).

In view of China's One Belt, One Road initiative, Latvia is also increasingly positioning itself as a potential overland gateway in northern Europe for Chinese exports (Pastore 2017, 152). Despite Latvia’s strong dependence on Russian gas supplies (Mišík 2010, 124), the country does not have a direct interest in the construction of alternative energy supply routes from Central Asia via the Caspian to Europe, simply because it is unlikely that these pipelines would be able to supply the Baltic region.

\section{Uploading of national interests}

Since their accession to the EU in 2004 and 2007, respectively, both Latvia and Romania have become more involved in Central Asia. To some extent, this might be the result of the top-down impact of their participation in the EU foreign policy-making process. To a larger extent, however, this is linked to the strategic shifts and reorientation process of their foreign policy in the aftermath of their dual accession to the EU and NATO. Indeed, prior to their accession to these organizations, Latvia and Romania's foreign policy was entirely dedicated to achieving membership. It is only after their accession that they started to (re-) conceptualize their role in their non-EU neighbourhood and to identify their new national interests (Angelescu 2011b; Kesa 2011; Micu 2010; Pastore 2013). This reorientation of their foreign policy also pushed them to find a niche for themselves within the EU's foreign policy, which would reflect their expertise and interests (Galbreath 2006, 122, 123; Kesa 2011, 87; Popescu 2010). ${ }^{7}$ In what follows, we explore to what extent both countries have sought to pursue their foreign policy goals towards Central Asia through the EU.

\subsection{Latvia}

Since 2013, Central Asia has been singled out by Latvia as a priority for EU foreign policy, which it now considers almost equally important as the Eastern Partnership (Latvian Ministry of Foreign Affairs 2013; Pastore 2016). Previously, Central Asia was given much less attention in Latvia's agenda for EU foreign policy (Jēkabsone 2013; Latvian Ministry of Foreign Affairs 2012). This policy change is undoubtedly related to Latvia holding the Rotating Presidency of the Council of the EU in the first half of 2015, which required the country to think strategically about the goals it wants achieve through the EU. Moreover, although the abilities of the Presidency to exert influence on EU decision-making have been reduced with the entry into force of the Lisbon Treaty, especially in the area of external policies, recent research on Poland's Council Presidency and its actions regarding the Eastern Partnership has shown that the incumbent can still be an influential actor in EU decision-making on external policies, especially when it comes to agenda-setting (Vandecasteele, Bossuyt, and Orbie 2013). In this regard, it is interesting to observe that Latvia set some ambitious goals concerning Central Asia in its Council Presidency agenda, namely to revitalize the EU strategy for Central Asia, which was adopted by the Council in 2007 (Council of the European Union 2007), and to make sure that the EU's development assistance to the region is more in tune with its political strategy (Interview 2; Latvian Ministry of Foreign 
Affairs 2014b). At a more concrete level, Latvia aspired to use the occasion of its Council Presidency to move the EU's Central Asia policy forward in areas of 'border security, counter-terrorism operations, WTO membership of Central Asian countries, strengthening of economic ties with Afghanistan, education, water resource management, energy efficiency and the building of a civil society' (Latvian Ministry of Foreign Affairs 2013, 10). The strong commitment to Central Asia in Latvia's Presidency agenda reflects above all the country's security interests in the region. This is explicitly mentioned in the 2012 annual report of Latvia's Ministry of Foreign Affairs:

In view of a gradual transfer of responsibility in Afghanistan to the Government of that country, and the engagement of Latvia in Afghanistan and a broader Central Asian region, the Latvian Presidency, by putting to use the EU Strategy for Central Asia and instruments for cooperation with Afghanistan, wishes to raise the profile of the region within the foreign policy of the European Union in the matters of security, economy and energy issues. (Latvian Ministry of Foreign Affairs 2012, 21, 22)

Latvia's urge to revitalize the EU's strategy for Central Asia also drew on the acknowledgement that the geostrategic environment of the region has evolved since 2007, with increased instability risks due to NATO's withdrawal from Afghanistan, China's growing influence and Russia's strong interest in maintaining control over the region (Pastore 2016, 5).

In trying to upload its national interests concerning Central Asia to the EU level, the Latvian Presidency mainly relied on two channels, both of which reveal the extent to which Latvia has familiarized itself with the formal and informal policy-making processes in Brussels. First, it teamed up with Germany - considered the main player in the field of EU-Central Asia relations - in taking a leading role in the 2015 review of the EU's strategy for Central Asia (Interview 1; Interview 3; Interview 4; Pastore 2016, 8). Alliance-building is a commonly used strategy in EU foreign policy (see e.g., Copsey and Pomorska 2014; Miskimmon 2007, 12). As a small and arguably insignificant member state, forming an alliance with the country that is by far the most influential member state when it comes to EU-Central Asia relations was clearly a strategic and well-calculated move. Second, the Latvian Presidency organized a variety of different level events in Brussels and Latvia and in European and Central Asian capitals with the aim of raising the profile of Central Asia among its fellow member states (Interview 1; Interview 3, Interview 4; Pastore 2016). Among other things, it organized an EU-Central Asia forum in Latvia on clean technologies and sustainable development, a conference in Brussels on the future of EU-Central Asia cooperation, a lab debate at the 2015 European Development Days in Brussels on women's economic rights in Central Asia and an EU-Central Asia ministerial meeting in Riga on education. $^{8}$

Although Central Asia is currently no longer singled out as a key foreign policy priority in Latvia's foreign policy, the Latvian Government remains committed to 'continue highlighting the geopolitical significance of the Central Asian region and keep the region's theme high on the EU agenda, as well as running cooperation projects both bilaterally and under EU programmes' (Latvian Ministry of Foreign Affairs 2017, 17; also see Pastore 2017).

Latvia admits that it seeks to utilize EU foreign policy mechanisms and instruments for Central Asia to pursue some of its foreign policy goals towards Central Asia, because it does not have the resources and capacities needed to pursue these goals on its own (Interview 2; Interview 4). Therefore, it actively seeks to influence the EU's agenda, and contributes to the implementation of the EU's policy by seconding national experts in 
those areas where it has a specific interest and expertise. Latvia, for instance, is very active in the EU's border management programme in Central Asia (BOMCA), ${ }^{9}$ in which it has trained Central Asian border guards and customs officers since 2007 (Interview 4; Latvian Ministry of Foreign Affairs 2013, 10; 2017, 17). In 2015-2018, it plays the lead role among the EU member states in implementing the programme (Latvian Ministry of Foreign Affairs 2017, 17; Pastore 2016, 11). Latvia is also actively engaged in the EU's Central Asia Education Platform (CAEP), which aims at strengthening education reforms in the region (Interview 4; Latvian Ministry of Foreign Affairs 2017, 17). Apart from hosting the EU-Central Asia ministerial meeting on education during its 2015 Council Presidency, the Latvian Government committed itself to assuming a leading role in the Vocational Education and Training component of the CAEP. In this regard, for instance, it organized the CAEP Regional Conference on National Qualifications Framework in 2016. ${ }^{10}$ Latvia has also been involved in EU projects on food security, which aim at approximating food standards in the region with EU standards. Latvia is increasingly keen to offer its transition and reform experience to contribute to the implementation of EU assistance programmes in Central Asia, as it has been doing for EU programmes in Georgia, Ukraine and Moldova (Jēkabsone 2013,2). In acknowledging that it has an important role to play in exemplifying to the post-Soviet states how a country can make it through de-Sovietization, democratization and marketization, Latvia has found an important niche for itself within EU foreign policy (see also Andrespok and Kasekamp 2012, 124; Galbreath 2006, 122, 123; Galbreath and Lamoreaux 2007, 116; Pastore 2016).

The biggest asset of the EU's policy towards Central Asia according to Latvia is that the EU offers regional cooperation, which has the best scope for dealing with cross-border issues, such as border control and water management (Interview 2). It is particularly in these - 'soft security' - areas that Latvia feels it is important to work with the EU because it is unable to address these issues on its own. Conversely, at the bilateral level of its relations with Central Asia, Latvia feels it has enough capacities to pursue certain goals on its own, which implies that part of its foreign policy towards Central Asia is conducted in parallel with or separately from the EU, in particular in the sphere of economic cooperation (Jēkabsone 2013; Latvian Ministry of Foreign Affairs 2012, 2013; Pastore 2017).

\subsection{Romania}

The fact that Romania's interests in Central Asia are less strong and pronounced compared to those of Latvia, is reflected in its involvement in the EU policy-making process, which is noticeably lower. The area where Romania has been most active at the EU level is the energy security domain, and in particular concerning the Trans-Caspian pipeline and Nabucco (Interview 1; Romanian Ministry of Foreign Affairs 2011, 2014, 2017b). Romania has invested considerable effort in lobbying other EU member states and institutional actors in order to get EU support for these projects (Micu 2010, 84). However, Romania has also pursued these goals bilaterally, in parallel with actions undertaken at the EU level (Interview 1; Romanian Ministry of Foreign Affairs 2011). For instance, Romania has had several meetings with Turkmenistan in the last few years, which all focused largely on securing access to Turkmenistan's gas reserves and on overcoming some of the political problems surrounding the construction of a Trans-Caspian pipeline (Eurasianet 2011, 2012). The Romanian Government openly admits that it is pursuing this dual track - i.e., acting on 
both the EU and the bilateral level - in pursuit of its strategic policy goal to become a major energy transport corridor between the Black Sea and the Caspian Sea areas (Interview 1; Romanian Government 2009).

Related to this, the Romanian Government would like to see more approximation in Central Asia with EU rules and practices, and in particular in the areas of transport, energy and environment. Therefore, Romania has also been pushing the EU level to establish closer institutional links between the Eastern Partnership and Central Asia (Interview 1; Interview 3). It has done so mainly at meetings of COEST, i.e., the preparatory Council meetings for issues relating to eastern Europe, Russia and Central Asia, where it has been actively calling on the EU to include Central Asian countries more in the mechanisms and instruments operational for the Eastern Partnership countries, such as TAIEX. ${ }^{11}$

Romania also wishes to contribute to the implementation of EU assistance initiatives in Central Asia, in particular in areas where it has specific expertise. Like Latvia, Romania does not have sufficient resources to provide extensive development assistance at the bilateral level. Seconding experts to the EU level is therefore an appealing alternative (Interview 1). In Central Asia, Romania contributes mainly to the EU's Water Initiative. Next to providing expert knowledge on water management at the project level (Romanian Ministry of Foreign Affairs 2012), it acts as chair of the 'Eastern Europe, Caucasus and Central Asia' (EECCA) working group of the EU Water Initiative, which works together with the EU programme 'Regional Environment Programme for Central Asia' (EURECA). ${ }^{12}$ The working group deals with issues of water supply and sanitation, as well as management of cross-border water resources.

Like Latvia, Romania prefers to pursue its economic interests in Central Asia fully separately from the EU and has been conducting an active economic diplomacy in the region (Embassy of Romania in Kazakhstan 2017a; Marin 2013). Similarly, in the higher education sphere, it has negotiated bilateral agreements with Kazakhstan, Uzbekistan and Turkmenistan, offering scholarships to students from these countries to study at Romanian high education institutes (Marin 2013, 3, 4; Romanian Ministry of Foreign Affairs 2017a). Turkmenistan is even one of the main recipients of Romanian scholarships (RoAid 2017). In the academic year 2015-2016, Romania offered no less than 132 scholarships to Turkmen students (Embassy of Romania in Kazakhstan 2017b). However, Romania is also actively involved in the EU's higher education initiatives in the region, namely Erasmus Plus and Tempus.

It is interesting to note that Latvia's efforts to bring more attention to Central Asia under its Council Presidency did not go unnoticed in Bucharest and were positively received by Romanian diplomats. In this regard, some social learning seems to have occurred in the sense that Romania has come to appreciate Latvia's approach - the combination of teaming up with an important member state and organizing a variety of different level events - and considers it as an example to be followed when they assume the Presidency of the Council in 2019 (Interview 1).

\subsection{Tentative explanations}

We end this section by offering some tentative explanations for the findings presented above. In doing so, we fall back on the four conditions we identified under which member states are likely to project national preferences onto the EU level (see Table 1). 
Table 1. Conditions determining the likelihood of uploading to EU level, applied to Latvia and Romania.

\begin{tabular}{|c|c|c|c|}
\hline & & Latvia & Romania \\
\hline Condition 1 & Perceived salience of a policy goal & $\begin{array}{l}\text { Central Asia singled out as foreign } \\
\text { policy priority (in 2012-2015) }\end{array}$ & $\begin{array}{l}\text { Significant stakes in Central } \\
\text { Asia, but not a foreign policy } \\
\text { priority }\end{array}$ \\
\hline Condition 2 & Carving out a niche & $\begin{array}{l}\text { - Central Asia as niche for Latvia } \\
\text { within EU foreign policy } \\
\text { - Border management } \\
\text { - Higher education }\end{array}$ & Water management \\
\hline Condition 3 & Perceived capabilities & $\begin{array}{l}\text { Perception of limited capabilities } \\
\text { to 'go it alone' }\end{array}$ & $\begin{array}{l}\text { Perception of limited } \\
\text { capabilities to 'go it alone' }\end{array}$ \\
\hline Condition 4 & $\begin{array}{l}\text { Degree of top-down Europeanization } \\
\text { of national foreign policy }\end{array}$ & $\begin{array}{l}\text { High degree of top-down } \\
\text { Europeanization }\end{array}$ & $\begin{array}{l}\text { Medium degree of top-down } \\
\text { Europeanization }\end{array}$ \\
\hline
\end{tabular}

How can we explain that Latvia has been more active at the EU level than Romania? From the analysis presented above, it is clear that Latvia scores 'better' on all four conditions than Romania. First, Latvia's stronger involvement at the EU level is connected to the fact that its interests in Central Asia are broader and more pronounced than those of Romania. Latvia has now even singled out Central Asia as a priority region for its foreign policy (cf. condition 1). Romania also has significant stakes in the region, but not to the extent that the region is prioritized in its foreign policy. Second, both Latvia and Romania seek to participate in EU policy towards Central Asia in those areas where they have specific expertise (including in the areas of border management and water management, respectively) (cf. condition 2) and where they lack the capacities and resources to 'go it alone' (cf. condition 3). Given their limited resources to offer bilateral development and technical assistance, providing this expertise through the EU is perceived by them as being more advantageous. However, these factors play out stronger in the case of Latvia, which - unlike Romania has immediate historical links with Central Asia. Having gone through a triple transition of de-Sovietization, democratization and marketization, the country seeks to capitalize on the notion that it is uniquely disposed to cooperate with Central Asia and to contribute its transition expertise to EU projects in the region (cf. condition 2). A final explanation can be found in the countries' different accession history. Latvia has joined the EU in 2004, giving it three years more time than Romania to adapt its domestic foreign policy machinery to EU foreign policy and to 'mature' as an EU foreign policy entrepreneur (cf. condition 4). In this context, also the fact that Latvia held the Council Presidency in the first half of 2015 plays a major role to the extent that this required the country to think strategically about the goals it wishes to pursue through the EU. This raises the question whether Central Asia would have occupied such a central place among Latvia's current priorities regarding EU foreign policy if the country had not been holding the Council Presidency in 2015. With Romania assuming the Council Presidency only in 2019, it remains to be seen whether the prospect of holding the Council Presidency will have a similar effect on the (re)formulation of its foreign policy priorities.

\section{Conclusion}

This article has focused on the involvement of new member states in the EU's policy towards Central Asia. In particular, it has explored Latvia and Romania's foreign policy goals towards the region and examined to what extent they try to pursue these goals through the EU rather 
than bilaterally. In doing so, the article started from the assumption that EU member states seek to project national preferences onto the EU level because bottom-up Europeanization can amplify their national foreign policy. At the same time, the national foreign policies of the member states manifest a strong tension between Europeanization and sovereign imperatives. This implies, among other things, that certain foreign policy actions continue to be conducted in parallel to or autonomously from EU policy.

The article found that the interests of Latvia and Romania in Central Asia are primarily security and economically related. Latvia, in particular, has strong interests in Central Asia and is increasingly eager to become more involved in the region. This is reflected in its growing engagement towards Central Asia at the EU level. While the article has also found evidence of Romanian attempts to project its interests in the region onto the EU level, Latvia appears to rely more extensively on the EU level to pursue its goals towards Central Asia and has strong ambitions to multiply its efforts to influence the EU's policy. To explain this finding, we made reference to the four conditions presented in the theoretical part of the article, which indicate under which circumstances EU member states are likely to upload national preferences at the EU level. At the same time, the article also found that both Latvia and Romania are increasingly active in strengthening their bilateral ties with the Central Asian countries, in particular in the economic field. This confirms the claim by Hadfield et al. (2017) that member states experience a tension between Europeanization and the sovereign prerogative to construct their own foreign policy. Moreover, our analysis has shown that Latvia and Romania seek to participate in EU policy in those areas where they have specific expertise and where they lack the capacities and resources to 'go it alone.' Given their limited resources to offer bilateral development and technical assistance, providing this expertise through the EU is perceived by them as being more advantageous.

To the (admittedly limited) extent that Latvia and Romania can be considered representative for the larger group of new member states, and in particular those that were once part of either the Soviet Union or the Soviet bloc, what can the findings tell us about the new member states as foreign policy actors involved in EU external policy-making? ${ }^{13}$ The findings are in line with existing research claiming that the participation of this group of member states in EU foreign and development policy is strongly - but not exclusively guided by security motivations (see e.g., Baun and Marek 2013; Lightfoot 2010). Latvia and, to a lesser extent, Romania see Central Asia as a source of instability and security threats, which could directly or indirectly affect them. Latvia, in particular, has several security concerns relating to Central Asia. Apart from being concerned about possible destabilization spillover from Afghanistan, Latvia is witnessing increasing cases of drugs trafficking, human trafficking, organized crime and illegal migration all coming from Central Asia through Russia. Therefore, Latvia has a direct interest in improving border management and drugs control capacities in the region. However, the country has limited means to provide direct development and technical assistance to Central Asia. Therefore, it considers, and uses, the EU's foreign and development policy towards the Central Asian countries as an instrument for pursuing its security-related goals vis-à-vis the region. In this regard, for instance, it sees the secondment of national border management specialists to the EU's BOMCA programme in Central Asia as more advantageous than offering direct border management support to the region. These observations also reflect the broader debate on the interlinkages between security and development within the national foreign policies of the new member states and links up with the claim presented in a growing body of literature that the new member 
states see development cooperation as a tool to achieve broader foreign and security policy aims rather than to reduce poverty as an end in itself (see e.g., Andrespok and Kasekamp 2012; Szent-iványi 2012).

The findings also indicate that the new member states, and in particular, those that joined the EU in 2004, have 'matured' as policy entrepreneurs within EU foreign policy-making, in the sense that they increasingly seek to project their national foreign policy interests onto the EU level. In this regard, they have 'watched and learned' from the older member states, and now use the same tactics and strategies, taking full account of their perceived strengths and weaknesses. That said, as the bottom-up dimension of Europeanization remains underresearched, especially from a theoretical perspective, further research is needed to theorize in a more systematic and rigid fashion under which conditions EU member states seek to project national foreign policy objectives onto the EU level.

A final remark that needs to be made regards the article's reliance on an instrumental approach to Europeanization. This article has focused predominantly on how EU foreign policy is instrumentalized by the new member states to advance their national foreign policy. Further research should concentrate on the more sociological aspects of Europeanization of the new member states' foreign policy towards Central Asia and beyond, including processes of socialization and identity change.

\section{Notes}

1. Kazakhstan, Kyrgyzstan, Tajikistan, Uzbekistan and Turkmenistan.

2. The EU depicts Central Asia as its 'far neighbourhood' (Spaiser 2015).

3. It should be noted that in positivist case study research the goal of most-likely cases is disconfirmatory (see e.g., Gerring 2007). In the present article, which is explorative in nature, the goal is to explore - rather than 'disconfirm' - the expectation that Latvia and Romania will actively use the EU level in pursuit of their policy goals towards Central Asia.

4. The small states literature defines a small state as a state that has a limited resource base, determined by factors such as geographical size, population size, economic weight, diplomatic network and military capabilities (Thorhallsson and Wivel 2006, 653, 654).

5. For more details on Latvia's role in the NDN, see Andžāns (2013).

6. Ventspils Grain Terminal, https://www.vgt.lv/eng/info.htm.

7. Interestingly, Spaiser (2015) argues that the EU itself focuses on 'niche' areas of security that are not occupied by other external actors in Central Asia.

8. Latvian Presidency, https://eu2015.lv/news/insights/2439-eu-central-asia-strategy-at-thecrossroads-of-growth-in-two-continents.

9. For an interesting piece on the EU's interest in border management in Central Asia, see Martin-Mazé (2015).

10. https://www.caep-project.org/riga2016/.

11. TAIEX stands for 'Technical Assistance and Information Exchange'. As a distinctive EU external assistance instrument, it provides support to public administrations regarding approximation, application and enforcement of EU legislation as well as facilitating the sharing of EU best practices.

12. See https://www.euwi.net/wg/eecca.

13. Although the extent to which one can generalize based on this two-case comparison to the larger group of cases is limited, it is nevertheless relevant to reflect on what the findings might tell us about the new member states as foreign policy actors involved in EU external policy-making. 


\section{Disclosure statement}

No potential conflict of interest was reported by the author.

\section{Notes on contributor}

Fabienne Bossuyt is an assistant professor at the Department of Political Science at Ghent University, where she teaches several courses within the EU Studies Master's programme, including a course on the European Neighbourhood Policy. Her doctoral research focused on the EU's influence in post-Soviet Central Asia. Her publications include articles in European Foreign Affairs Review (2009, 2011 and 2013), Journal of Contemporary European Research (2013), European Integration online Papers (2013), Comparative European Politics (2014), Journal of Contingencies and Crisis Management (2014), Democratization (2014 and 2017), Cambridge Review of International Affairs (2015), Communist and Post-Communist Studies (2016) and East European Politics and Societies (2017).

\section{References}

Andrespok, Evelin, and Andres I. Kasekamp. 2012. Development cooperation of the Baltic States: A comparison of the trajectories of three new donor countries. Perspectives on European Politics and Society 13, no. 1: 117-130.

Andžāns, Māris. 2013. The northern distribution network and its implications for Latvia. In Northern distribution network: Redefining partnerships within NATO and beyond, ed. Andris Sprūds and Diāna Potjomkina, 9-30. Riga: Latvian Institute of International Affairs.

Angelescu, Irina. 2011a. Punching below its weight? Europeanization and Romanian foreign policy. Paper presented at the EUSA 12th Biennual Conference, March 3-5, Boston, USA. https://euce. org/eusa/2011/papers/7j_angelescu.pdf.

Angelescu, Irina. 2011b. New Eastern perspectives? A critical analysis of Romania's relations with Moldova, Ukraine and the Black Sea region. Perspectives: Review of International Affairs 9, no. 2: 123-142.

Baun, Michael, and Dan Marek. 2013. The foreign policies of the new member states. A framework for analysis. In The new member states and the European Union: Foreign policy and Europeanization, ed. Michael Baun and Dan Marek, 1-21. London: Routledge.

Bilčík, Vladimir. 2010. Foreign and security policy preferences. In From listening to action? New member states in the European Union, ed. Darina Malova, Marek Rybář, Vladimír Bilč́́k, Erik Láštic, Zuzana Lisoňová, Matúš Mišík and Martin Pašiak, 129-144. Bratislava: Comenius University.

Central Statistical Bureau of Latvia. 2017. Foreign trade database. https://www.csb.gov.lv/en/ statistikas-temas/foreign-trade-database-30721.html (accessed June 7, 2017).

Cooley, Alexander. 2012. Great games, local rules. Oxford: Oxford University Press.

Copsey, Nathaniel, and Tim Haughton. 2009. The choices for Europe: National preferences in new and old member states. JCMS: Journal of Common Market Studies 47, no. 2: 263-286.

Copsey, Nathaniel, and Karolina Pomorska. 2010. Poland's power and influence in the European Union: The case of its eastern policy. Comparative European Politics 8, no. 3: 304-326.

Copsey, Nathaniel, and Karolina Pomorska. 2014. The influence of newer member states in the European Union: The case of Poland and the Eastern partnership. Europe-Asia Studies 66, no. 3: 421-443.

Council of the European Union. 2007. The European Union and Central Asia: Strategy for a new partnership, 10113/07, Brussels. https://www.consilium.europa.eu/uedocs/cms_data/librairie/PDF/ EU_CtrlAsia_EN-RU.pdf (accessed February 12, 2013).

Darina, Malova, Marek Rybář, Vladimír Bilč́́k, Erik Láštic, Zuzana Lisoňová, Matúš Mišík and Martin Pašiak, eds. 2010. From Listening to Action? New member states in the European Union. Bratislava: Comenius University.

Denca, Sorin S. 2009. Europeanization of foreign policy: Empirical findings from Hungary, Romania and Slovakia. Journal of Contemporary European Research 5, no. 3: 389-404. 
Denca, Sorin S. 2013. Romania: The Black Sea Atlanticist. In The new member states and the European Union. Foreign policy and Europeanization, ed. Michael Baun and Dan Marek, 175-189. London: Routledge.

Embassy of Romania in the Republic of Kazakhstan. 2017a. Bilateral Relations: Economic Relations. https://astana.mae.ro/en/node/395 (accessed June 7, 2017).

Embassy of Romania in the Republic of Kazakhstan. 2017a. Romania and Turkmenistan have partnership of strategic value; economic potential must be capitalised on. https:/astana.mae.ro/ en/romania-news/7414 (accessed June 7, 2017).

Eurasianet. 2011. Nabucco postponed, Turkmenistan focuses on trans-Caspian. 12 May. https://www. eurasianet.org/node/63504 (accessed April 16, 2012).

Eurasianet. 2012. Turkmenistan international relations. 12 October. https://www.eurasianet.org/ node/66065 (accessed October 14, 2012).

Galbreath, David J. 2006. The Baltic States and the European neighbourhood policy: Maximising the voices of small nations. In Global and regional security challenges: A Baltic outlook, ed. Heli Tiirmaa-Klaar and Tiago Marques, 102-126. Tallinn: Tallinn University Press.

Galbreath, David J., and Jeremy W. Lamoreaux. 2007. Bastion, beacon or bridge? Conceptualising the Baltic logic of the EU's neighbourhood. Geopolitics 12, no. 1: 109-132.

Gerring, John. 2007. Is there a (viable) crucial-case method? Comparative Political Studies 40, no. 3: 231-253.

Gower, Jackie. 2010. EU member states in Central Asia. In The European Union and Central Asia, ed. Alexander Warkotsch, 33-47. Oxon: Routledge.

Hadfield, Amelia, Ian Manners, and Richard G. Whitman. 2017. Conceptualizing the foreign policies of EU member states. In Foreign policies of EU member states. Continuity and Europeanisation, ed. Amelia Hadfield, Ian Manners, and Richard G. Whitman, 1-20. London: Routledge.

Hill, Christopher, and Rueben Wong. 2011. Many actors, one path? The meaning of Europeanization in the context of foreign policy. In National and European foreign policy: Towards Europeanization, ed. Rueben Wong and Christopher Hill, 210-232. London: Routledge.

Jēkabsone, Anete. 2013. The Baltic states and Central Asia. EU-Central Asia Monitoring Policy Brief, no. 11

Kesa, Katerina. 2011. Latvian and Lithuanian policy in the eastern neighbourhood: Between solidarity and self promotion. Perspectives: Review of International Affairs 9, no. 2: 81-100.

Keukeleire, Stephan, and Tom Delreux. 2014. The foreign policy of the European Union. Basingstoke: Palgrave Macmillan.

Latvian Ministry of Foreign Affairs. 2012. Annual report by the Minister of Foreign Affairs on activities performed and planned in national foreign policy and European Union matters. https://www.mfa. gov.lv/data/foreign_policy_report_for_2012_eng_2301.pdf (accessed February 2, 2014).

Latvian Ministry of Foreign Affairs. 2013. Annual report by the Minister of Foreign Affairs on activities performed and planned in national foreign policy and European Union matters. https://www.mfa. gov.lv/data/21012014_arlietu\%20ministra\%20zinojums-en.pdf (accessed February 2, 2014).

Latvian Ministry of Foreign Affairs. 2014a. Website. https://www.mfa.gov.lv/ (accessed March 11, 2014).

Latvian Ministry of Foreign Affairs. 2014b. Press release. Edgars Rinkēvičs: Latvia supports development of parliamentary democracy in Kyrgyzstan. February 6. https://www.mfa.gov.lv/en/ news/press-releases/2014/february/06-2/ (accessed March, 11 2014).

Latvian Ministry of Foreign Affairs. 2016a. Annual report on accomplishments and further work with respect to national foreign policy and the European Union: 2015-2016. https://www.mfa. gov.lv/images/Annual_report_2016_ENG.pdf (accessed June 7, 2017).

Latvian Ministry of Foreign Affairs. 2016b. Young leaders from the Eastern partnership, Central Asia and the Balkan countries are learning European law and economics in Latvia. https://www.mfa. gov.lv/en/component/content/article/50350-young-leaders-from-the-eastern-partnership-centralasia-and-the-balkan-countries-are-learning-european-law-and-economics-in-latvia?Itemid=353 (accessed June 7, 2017).

Latvian Ministry of Foreign Affairs. 2017. Annual report on accomplishments and further work with respect to national foreign policy and the European Union: 2016-2017. https://www.mfa.gov.lv/ images/uploads/infografiki/Foreign_Policy_Report_2016_ENG.pdf (accessed June 7, 2017). 
Lightfoot, Simon. 2010. The Europeanisation of international development policies: The case of Central and Eastern European states. Europe-Asia Studies 62, no. 2: 329-350.

Marin, Georgiana. 2013. Romania and Central Asia. EU-Central Asia Monitoring Policy Brief, no. 12. Martin-Mazé, Médéric. 2015. Unpacking interests in normative power Europe. JCMS: Journal of Common Market Studies 53, no. 6: 1285-1300.

Micu, Mircea. 2010. Romanian security in an evolving European context. Romanian Journal of European Affairs 10, no. 2: 79-89.

Mišík, Matus. 2010. Security first: Energy policy in the new member states of the European Union. In From listening to action? New member states in the European Union, ed. Darina Malova, Marek Rybáŕ, Vladimír Bilčík, Erik Láštic, Zuzana Lisoňová, Matúš Miš́k, and Martin Pašiak, 101-128. Bratislava: Comenius University.

Miskimmon, Alister. 2007. Germany and EU foreign policy: Between Europeanization and national adaptation. Basingstoke: Palgrave Macmillan.

Nasra, Skander. 2011. Governance in EU foreign policy: Exploring small state influence. Journal of European Public Policy 18, no. 2: 164-180.

Ozolina, Zaneta, and Toms Rostoks. 2006. Latvian outlook on the European Union common foreign and security policy. In Global and regional security challenges: A Baltic outlook, ed. Heli TiirmaaKlaar and Tiago Marques, 86-101. Tallinn: Tallinn University Press.

Pastore, Gunta. 2013. Small new member states in the EU foreign policy: Towards 'small state smart strategy'? Baltic Journal of Political Science 2, no. 2: 67-84.

Pastore, Gunta. 2016. Leadership through the European Union Council Presidency: Latvia and Central Asia. LIIA report, March 2016. Riga: Latvian Institute of International Affairs.

Pastore, Gunta. 2017. Latvia and Central Asia: From visibility to practical work. In Latvian foreign and security policy. Yearbook 2017, ed. Andris Spruds, Ilvija Bruge, and Karlis Bukovskis, 151-162. Riga: Latvian Institute of International Affairs.

Peyrouse, Sebastien. 2009. Business and trade relations between the EU and Central Asia. EUCAM Working Paper, no. 1.

Pisarska, Katarzyna. 2008. The role of the new member states in the developing of the EU's Eastern agenda in the years 2004-2007: Perceptions of EU officials. Pulaski Report, No. 1. Warsaw: Pulaski Foundation.

Popescu, Liliana. 2010. Europeanization of Romanian foreign policy. Romanian Journal of European Affairs 10, no. 4: 50-65.

Raik, Kristi, and Grzegorz Gromadzki. 2006. Between activeness and influence. The contribution of new Member states to EU policies towards the Eastern neighbours. Tallinn: Open Estonia Foundation.

RoAid. 2016. National Report on the official development assistance provided by Romania in 2015. https://www.roaid.ro/uploads/documents/101/RoAid_Report2015_eng_website.pdf (accessed June 7, 2017).

RoAid. 2017. List of countries which benefited from scholarships from the Ministry of Education and Scientific Research in 2014 and 2015. https://roaid.ro/uploads/documents/69/AsistentaMECS. pdf (accessed June 7, 2017).

Romanian Government. 2009. The 2009-2012 Government Programme. Chapter 21 - Romania's foreign policy. Bucharest.

Romanian Ministry of Foreign Affairs. 2011. Priorities of Romanian diplomacy in 2011. https://www. mae.ro/en/node/2147 (accessed February 2, 2014).

Romanian Ministry of Foreign Affairs. 2012. Development cooperation policy report 2011. https:// www.mae.ro/sites/default/files/file/userfiles/file/pdf/aod/2012.08_oda_raportare_2011_en.pdf (accessed February 2, 2014).

Romanian Ministry of Foreign Affairs. 2014. Central Asia. https://www.mae.ro/en/node/2109 (accessed February 2, 2014).

Romanian Ministry of Foreign Affairs. 2017a. Central Asia. https://www.mae.ro/en/node/2109 (accessed March 17, 2017).

Romanian Ministry of Foreign Affairs. 2017b. Programul de Guvernare 2017-2020. https://www. mae.ro/sites/default/files/file/anul_2017/2017.02.20_program_de_guvernare.pdf (accessed March 17, 2017). 
Romania's Permanent Delegation to NATO. 2017. Romania in Afghanistan. https://nato.mae.ro/en/ node/371 (accessed June 7, 2017).

Spaiser, Olga. 2015. The EU as a security actor in Central Asia: Minor but not marginal. L' Europe en Formation 375: 83-105.

Szent-iványi, Balazs. 2012. Hungarian international development cooperation: Context, stakeholders and performance. Perspectives on European Politics and Society 13, no. 1: 50-65.

Thorhallsson, Baldur, and Anders Wivel. 2006. Small states in the European union: What do we know and what would we like to know? Cambridge Review of International Affairs 19, no. 4: 651-668.

Tiirmaa-Klaar, Heli. 2006. The quest for stability beyond the new eastern borders of the EU and NATO: Building multilateral security governance. In Global and regional security challenges: $A$ Baltic outlook, ed. Heli Tiirmaa-Klaar and Tiago Marques, 196-228. Tallinn: Tallinn University Press.

Vanaga, Nora. 2017. Security policy of Latvia: Shaping deterrence posture. In Latvian foreign and security policy. Yearbook 2017, ed. Andris Spruds, Ilvija Bruge and Karlis Bukovskis, 63-75. Riga: Latvian Institute of International Affairs.

Vandecasteele, Bruno, Fabienne Bossuyt, and Jan Orbie. 2013. Unpacking the influence of the Council Presidency on European Union external policies: The Polish Council presidency and the eastern partnership. European Integration Online Papers 17, no. 5: 1-28.

Vilpišauskas, Ramūnas. 2011. National preferences and barging of the new member states since the enlargement of the EU: The Baltic states - still policy takers? Lithuanian Foreign Policy Review 25, no. 2: 9-32.

Wong, Rueben, and Christopher Hill. 2011. Introduction. In National and European foreign policy: Towards Europeanization, ed. Rueben Wong and Christopher Hill, 1-18. London: Routledge.

\section{Interviews}

Interview 1: Romanian official, Romania’s Permanent Representation to the EU, Brussels, 2 April 2015. Interview 2: Latvian official, Latvia’s Permanent Representation to the EU, Brussels, 27 February 2014. Interview 3: Official from the Central Asia division of the European External Action Service, Brussels, 17 March 2015.

Interview 4: Official from the office of the EU Special Representative for Central Asia, Brussels, 25 November 2016. 